\title{
TRAP1 wt Allele
}

National Cancer Institute

\section{Source}

National Cancer Institute. TRAP1 wt Allele. NCI Thesaurus. Code C127911.

Human TRAP1 wild-type allele is located in the vicinity of $16 \mathrm{p} 13.3$ and is approximately 66 $\mathrm{kb}$ in length. This allele, which encodes heat shock protein $75 \mathrm{kDa}$, mitochondrial, plays a role in both AT Pase activity and protein folding. 